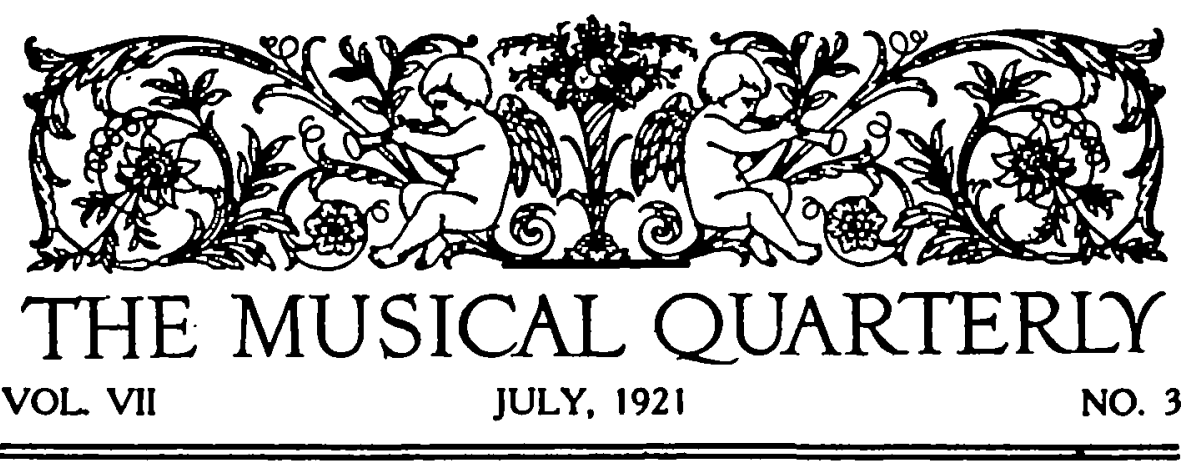

\title{
AMERICA IN THE ARTS
}

\section{By BABETTE DEUTSCH}

A

$\mathrm{N}$ American poet declares that poetry is in advance of music in this country, thereby opening up a controversy fascinating to poets and composers alike. The substance of this condemnation, if so harsh a word is here permissible, is that the composer has failed to develop a national school, a genuinely American music. German classicism, French impressionism, Italian lyrism have a stamp of their own, which, whether one like it or not, one recognizes as peculiar to itself. But while there are American composers who speak with an individual accent, as a group they have failed to cultivate or to define a national idiom.

The poets, on the other hand, as many competent musicians agree, have triumphed over the diversity of a huge and complex group. They have hearkened to the voice of Whitman, the great forerunner,

Poets to comel orators, singers, musicians to come!

Not to-day is to justify me and answer what $I$ am for,

But you, a new brood, native, athletic, continental, greater than before known,

Arouse! for you must justify me.

I myself but write one or two indicative words for the future,

I but advance a moment only to wheel and hurry back in the darkness.

I am a man who, sauntering along without fully stopping. turns a casual look upon you and then averts his face, Ieaving to you to prove and define it,

Expecting the main things from you.

In the Chicago Poems of Carl Sandburg, in the Spoon River Anthology those few indicative words are proven and defined 
with a vigor and a vividness not matched by the musicians, whom, it will be noted, Whitman calls upon equally with the poets.

The fundamental question, however, is not which of the arts leads, but rather what is "one hundred per cent. American," æsthetically speaking. What spirit informs Whitman and Masters and Sandburg that distinguishes them from their English confrères, as well as from the herd of minor American poets? Contrast Pound and T. S. Eliot with Aldous Huxley, and discover what curious streak of native wit sets them off from the smooth numbers of the author of "Leda." Louis Untermeyer claims that the essential character of American poetry as such is racy youth and energy. But these terms are inadequate to describe so definitely an American poet as Emily Dickinson, whose lyrics, Mr. Untermeyer regretfully notes, have not been set by any American composer. The musicians themselves have been at some pains to define this elusive element. Daniel Gregory Mason, whose friendship with William Vaughn Moody would entitle him to speak if he had never made any of his own interesting contributions to the world of arts and letters, translates energy into high nervous tension, and youth into constant restless motion. This definition, which is also a criticism, may be true of the cities, but it fails to account for a Robert Frost, whom London could not divert from his view of north of Boston, or for the serene and sharp penetration of an Edward Arlington Robinson. Mason, seeking a spiritual strength which he does not find in the pot-boiling host of potential burners of rivers, confesses that it is easier to describe what Americanism in art is not than what it is.

This confession of its negative character is fairly an implication that American culture is polyglot. It is obvious that an artist expressing the Oriental color and golden bloom of California would not be expressing at the same moment the overflowing ant-hills, the steel strength of Eastern cities. The poet-using the word generically to include the composer-who treats of the luxuriant Savannahs does not sing as well of the Great Lakes.

One of the reasons why it is hard to talk about American culture is that we have no American capital from which it naturally flows. Abroad, in France or Germany, in Italy or Austria or even Russia, the capital has long been the cultural centre. Paris or Petrograd, London or Vienna were for years almost solitary lanterns, flashing their rays into the furthest corners of the dark provinces. The United States, on the contrary, because it boasts some three capitals, has actually none. The nervous shriek of New York clamors stridently against the Anglicized Boston accent; 
the polite voice of the Back Bay is drowned by the raucous shout of Chicago. There is no cultural madus vioendi. One is apt to despair with Mr. Mason, to say simply that American music is not French or German or Italian, on the one hand, and that it is not Indian or Negro, on the other.

This view of a polyglot people is not the least difficulty in the way of establishing a coherent individual art-form. The composer, as Leo Sowerby affirms, is thereby driven back to mere imitation. He instances many who are composing very fine music which, because it is largely influenced by French, Russian, or German models, is neither individual nor national in character. As examples of distinctively American music, he brings forward the first movement of John Alden Carpenter's Symphony, parts of his Concertino, and the last movement of De Lamarter's Sonata for the violin. These things Sowerby describes as our own by virtue of their big sweep, their vigor, their lack of sentimentality, affectation and diffuseness. As a matter of fact, sentimentality is one of the great American vices, or virtues, as one chooses to see it. Even Whitman is sentimental, and no one would ever clear him of the charge of diffuseness. One is brought up sharply by the question as to whether Ella Wheeler Wilcox and Carrie Jacobs Bond or John Gould Fletcher and John Powell are more expressive of these States. But putting this aside for the moment, as not immediately relevant, we are brought back to Leo Sowerby's declaration that while Carpenter, De Lamarter, Powell and Henry F. Gilbert equal in power and exceed in technique poets of the rank of Pound, Masters, Sandburg and Lindsay, he finds that in each case the composers' idiom, as distinguished from the poets', is more a purely personal than a national one. Sowerby's disposition of the use of Indian or Negro tune-stuff as misdirected energy or sheer laziness opens up fresh fields for argument.

For Indian and Negro melodies are our closest approach to the folk-song. And it is the lack of this basic foundation of a national art, declare many critics, that invalidates any discussion of American music. Sowerby's stress upon our AngloSaxon tradition should point at the same time to another source of folk-music. The Creole songs of Louisianna, the tradition of English balladry, even more, which still echoes on the rocky trails of Kentucky and Virginia, are too often neglected.

But it is interesting to note that the folk-song itself is being brought into question. As too many cooks spoil the broth, so the number of races confined in our national melting-pot preclude the dominance of any particular strain. Nor can any peculiarly 
popular art develop within three hundred years. So the lovers of folk-song lament. Against such argument there is at least one American composer who lifts a protestant voice. According to Emerson Whithorne we are crying for the moon, nay, we are howling for a void. Properly speaking, there is no such thing as a folk-song. Any artist who has worked in collaboration should be quick to grasp Mr. Whithorne's point. The conception of a group creating an art-work is actually as romantic a notion as that of Rousseau's fearless savage. This does not mean that there can be no communal contribution to art. There is no question but that any genuinely popular melody or ballad or dance-step or the racy vulgar metaphor which we despise as slang may change in the process of acceptance. But all of these are the invention of an individual. So too a folk-song, if one examines its elements, is nothing more nor less than a popular catch. It is a song not created wholly and spontaneously by a group-but almost surely re-created by the group. It is like the street-ballad which the organ-grinder wheezes out before your window, like any bit of rag-time chorused by an approving audience. In its pristine state there is small difference between the production of a trouvère of Provence or of an Irving Berlin.

It is curious that of all the composers who rush to their own defense none of them mentions the significant potentialities in jazz and syncopation. These are the folk-music of America, whether the musicians like it or not. Lindsay knows it:

The banjos rattled, and the tambourines Jing-jing-jingled in the hands of Queens!

and
Pat black bucks in a wine-barrel room, Barre-house kings, with feet unstable, Sagged and reeled and pounded on the table, Pounded on the table.
Beat an empty barrel with the handle of a broom,
Hard as they were able, Boom, boom, BOOM,-
With a gill umbrella and the handle of a broom, Boomlay, boomlay, boomlay, BOOM.
THEN I had religion, then I had a vision. I could not turn from their revel in derision. THEN I SAW THE CONGO CREEPING THROUGH THE BLACK, Cutting through tho Jungle with a golden track.

It may easily be discredited, as having its roots in that negro tune-stuff, those African rhythms from which we strive to 
extricate ourselves. But it has something else, something that is essential to folk-music all over the world: the stamp of popular approval. It is a fact worth noting that the national anthem never is sung with the same hearty joy and strong emotion with which an audience, even of Northerners, greets the tune of "Dixie."

Admitting all this, one cannot help admitting at the same time that poets of the calibre of Masters and Sandburg, poetry like 'Mountain Interval' or 'The Golden Whales of California,' have a quality which is not to be found even in the music of Charles T. Griffes or Henry F. Gilbert. The poets are apt to overlook one of the chief reasons for their own relatively rapid progress. Certainly many of them go the primrose path of popularity, rather than toil to create either a national or a distinctly individual art. But the musicians, giving themselves to an ideal, have a yet harder row to hoe. Mason cites César Franck, working in obscurity forty years, teaching piano to Parisian schoolgirls for a few francs, despised by the academic and the fashionable musical world, as an example of what the composer's struggle must too often be. Mason recommends this arduous ungrateful labor to the talented musician. Marion Bauer explains the slow development of music in America as due to the posing of so strenuous an ideal. And Emerson Whithorne dots the " $i$ " and crosses the " $t$ " by writing musical comedies to Gouverneur Morris's libretto:

\footnotetext{
He who only toils for fame

I pronounce a silly Billy:

I can't dine upon a name

Or look dressy in a lily.

And-oh shomeful truth to utter!

I soon't live on bread and butter.
}

The path of Parnassus is difficult enough, even mounted upon Pegasus, when the editorial complex regarding public taste clings to the bridle. But if the poet finds recognition slow to come, the composer has more reason to complain. For the musician's lot, like the policeman's in the famous ballad, is not a happy one. In the first place, the medium employed by the composer is far more stubborn than that which the poet uses. The latter is using the oldest and most familiar stuff in his world. It is a common joke that words are a means to conceal thought, and it may be a corollary that they are a means to express emotion. By the same token, music may say more simply and more fully what the algebraic symbols of literature fail to convey. Nevertheless, the poet has the advantage of the composer because while 
he has to learn technique, he does not have to learn the very medium in which he works. Edward Burlinghame Hill describes the situation very nicely when he declares that music, unlike poetry, is "a language ... painfully acquired . . . with few of the instinctive qualities of a mother-tongue."

Furthermore, as Mr. Hill eloquently points out, the student is apt to learn it with a strong German accent or a French turn of phrase. The very process of learning, influences his ultimate apprehension of the thing learned, and the future manner in which he uses it. "Musically," writes Mr. Hill, "we are still nouveaux riches, striving to speak grammatically . . . still perplexed as to how to use our musical knives and forks . . . and much inclined to answer 'yes, ma'am' and 'yes, sir' in esthetic servility."

But the difference between the poet's road and the composer's is far greater than this. One can master a typewriter in a few weeks, while the task of writing out laborious scores must inevitably and continuously take precious time from the business of composition. An editor, particularly during a crisis in the paper market, may be hard to reach. But a conductor who will give a hearing to one's score, much less undertake to give it orchestral presentation, or a music publisher who will risk the enormous expense of engraving plates for a book of sonatas, are creatures altogether exceptional. Putting aside for the moment the question of his personal gift and his mastery of technique, the sheer mechanical difficulties which the composer must face are as awful as they are inescapable. And there is no end, not merely to making books, but to making solos and symphonies.

The hope of American musicians, like that of American poets, seems to lie not so much in striving to establish a school, nor even to express an Americanism which is overlaid with older traditions. It lies rather in a frank acknowledgment of their problems, in a sincere effort to express a personality colored by environment but not created by it. The artist is eccentric rather than eclectic, but not for the sake of eccentricity. He is conservative in his appreciation of the foreign tradition from Palestrina to Stravinsky. He is radical in his effort to get at the roots of an art that reflects the oldest emotions in the world, in the terms of his contemporary apprehension of them. 